\title{
Active structures and thermal state of the Piton de la Fournaise summit area revealed by combined UAV magnetic and thermal infrared measurements
}

\author{
Lydie Gailler ${ }^{*}$, Philippe Labazuy ${ }^{\alpha}$, Edouard Régis $^{\beta}$, Aline Peltier $\gamma, \delta$, Valérie Ferrazzini $\gamma, \delta$ \\ ${ }^{\alpha}$ Université Clermont Auvergne, CNRS, IRD, OPGC, Laboratoire Magmas et Volcans, F-63000 Clermont-Ferrand, France. \\ $\beta$ Université Clermont Auvergne, CNRS, Observatoire de Physique du Globe de Clermont, F-63000 Clermont-Ferrand, France.

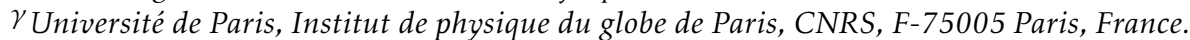 \\ ${ }^{\delta}$ Observatoire Volcanologique du Piton de la Fournaise, Institut de physique du globe de Paris, F-97418 La Plaine des Cafres, France.
}

\begin{abstract}
In this study, we demonstrate the strong potential of combining Unmanned Aerial Vehicle (UAV)-based thermal infrared (IR) and magnetic measurements to image the thermal state of volcanic edifices, as well as the distribution of active volcano-tectonic features at depth. Since magnetization is strongly dependent on temperature and alteration, thermally active structures are also associated with a decrease in magnetization. Based on the analysis of recent combined magnetic and infrared acquisitions, we focus on the recent evolution of the summit activity at Piton de la Fournaise. The comparison clearly highlights zones of major thermal activity, alteration and high permeability, and potentially areas of low mechanical resistance. Those observations provide information on preferential pathways for future activity, and also provide constraints on fluid transfer, diffusion, and cooling processes occurring within the volcano subsurface. Through reiterations, such combined UAV measurements are therefore particularly relevant in monitoring volcanic hazards before, during and after eruptions.
\end{abstract}

\section{RÉSUMÉ}

Cette étude illustre l'intérêt de combiner des mesures thermiques infrarouge et magnétiques par drone pour imager l'état thermique des édifices volcaniques, ainsi que la distribution des structures volcano-tectoniques actives en profondeur. L'aimantation étant fortement dépendante de la température et de l'altération, les structures thermiquement actives sont également associées à une diminution de l'aimantation. Sur la base de l'analyse combinée de récentes acquisitions magnétiques et infrarouges, nous nous concentrons sur l'évolution de l'activité récente du sommet du Piton de la Fournaise. Cette comparaison met en évidence des zones d'activité thermique importante, d'altération et de forte perméabilité, et potentiellement des zones de faible résistance mécanique. Ces observations renseignent sur les zones d'intrusions préférentielles et offrent des contraintes sur les transferts de fluides, la diffusion et les processus de refroidissement. La réitération de telles mesures par drone s'avère donc particulièrement pertinente pour contribuer au suivi des aléas volcaniques avant, pendant et après les éruptions.

Keywords: Piton de la Fournaise; UAV magnetic and IR surveys; Volcano monitoring; Thermal anomalies; Volcano-tectonics; Weakness zones

\section{INTRODUCTION}

Magma transfer pathways from the magma plumbing system to the surface are strongly dependent on the inherited structure and the thermal state of the edifice [e.g. Patrick and Witzke 2011; Wessels et al. 2013; Antoine et al. 2017; Dumont et al. 2019; Bouligand et al. 2020]. Thus, their evolution through time should be as precisely imaged as possible in order to help to image potential preferential pathways for future activity (i.e. weakness zones such as pre-existing fractures, previous intrusive fissures and altered area). The thermal infrared (IR) method enables temperature anomalies to

${ }^{*}$ Corresponding author: lydie.gailler@uca.fr be mapped, temperature being the most significant parameter for following fluid movement, as well as the imaging of associated heat flows; moreover, it highlights deep structures connected with the surface [Finn et al. 2018]. On active volcanoes, magma bodies may generate significant heat fluxes by sub-surface conduction and convection of magmatic fluids [Bouligand et al. 2019]. At the surface, thermal anomalies coincide with permeable zones (for example scoria cones, fractures, 'a' ā lava flows, lava tubes, pit-craters), where hot, rising fluids are drained or convectively released [e.g. Antoine et al. 2017].

Magnetization is also a powerful tool for addressing such issues in volcanic contexts. First, it can be used to highlight contacts between formations of different 
composition and age [Blakely 1995; Araña et al. 2000; Gailler and Lénat 2012], thus providing information on pre-existing structures at depth.

The Earth's magnetic field is undoubtedly affected by magnetization heterogeneities due, at least in part, to volcanic processes. Time or spatial-induced variations of magnetization can be recorded during an eruptive event [Zlotnicki et al. 1993]. Recent studies have shown the potential of magnetic field measurements to image temperature anomalies (due to the strong influence of temperature on magnetization) and mechanical heterogeneities [for example fracturing and alteration; Gailler and Lénat 2012; Gailler and Kauahikaua 2017; Bouligand et al. 2019; Dumont et al. 2019]. Most of the high temperature structures are also associated with a decrease in magnetization [Hunt et al. 1995] near or over the Curie temperature at which minerals lose their remnant magnetization. Therefore, the two parameters can be combined and used to provide constraints on fluid transfer, diffusion, and cooling processes.

The possibility of combining thermal IR and magnetization to investigate the thermal state of a volcanic edifice is thus highly promising for producing improved 3D images of inherited and active volcanic structures [e.g. Antoine et al. 2020]. High-resolution UAV thermal IR and magnetization mapping is now fully operational [James et al. 2006; Catalán et al. 2014; Antoine et al. 2020; Gavazzi et al. 2020; Gailler et al. 2021] and can be used to trace the geometry of structures and weaker zones, as well as magmatic and hydrothermal systems at depth with precision, i.e. rapidly and homogeneously. Over the longer term, time lapses, with their repeated measurements, can be used to quantify the spatio-temporal (i.e. 4D) evolution of these zones and structures and therefore to help prevent associated hazards. In this context, a purpose-built multi-method geophysical survey was carried out over the summit area of Piton de la Fournaise in November-December 2020.

Piton de la Fournaise (PdF; Figure 1) is one of the most emblematic "volcano laboratories" around the world [e.g. Bachèlery 1981; Lénat et al. 2012b; Peltier et al. 2021, and references therein] in which to conduct such investigations. Highly active, accessible, and closely monitored by the Observatoire Volcanologique du Piton de la Fournaise (OVPF) from Institut de Physique du Globe de Paris, PdF constitutes an ideal place to experiment new methodologies. Here we present the combination between ground and innovative Unmanned Aircraft Vehicle (UAV) geophysical surveys. The main goal of this new experiment is to improve monitoring and provide warning of volcanic hazards, by evolving towards an integrated 4D model of the volcano's structure [Gailler et al. 2021]. PdF is characterized by complex volcanic systems and phenomena, all associated with various hazards among which: 1) recurring eruptive activity, with more than two eruptions per year on average (up to 5 in 2019), associated with different geometries of dyke or sill injections in depth [e.g. Peltier et al. 2005; 2009a; Tridon et al. 2016; Smittarello et al. 2019] with a risk, albeit small (i.e. $5 \%$ ), of eruptions in inhabited areas [Chevrel et al. 2021]. This eruptive activity is fed by a deep magma plumbing system [e.g. Boudoire et al. 2019] whose shallowest reservoir is located about $2.5 \pm 1 \mathrm{~km}$ below the summit craters [e.g. Peltier et al. 2009b; 2018]; 2) a highly active hydrothermal system just below the summit crater [Barde-Cabusson et al. 2012; Lénat et al. 2012c; Dumont et al. 2019], with the occurrence of 17 phreatomagmatic eruptions inside the Dolomieu crater and several summit collapses since the $18^{\text {th }}$ century [Villeneuve and Bachèlery 2006; Michon et al. 2013]; 3) a potentially active sliding plane below the eastern Flank [Got et al. 2013; Tridon et al. 2016; Poland et al. 2017]. Partial collapses of this flank have already occurred in the past [Bachèlery 1981; Labazuy 1996; Merle and Lénat 2003; Michon and Saint-Ange 2008; Oehler et al. 2008; Merle et al. 2010], and could have generated tsunami [Kelfoun et al. 2010].

In this study, we focus on the summit part of the PdF, beneath which lies the shallow plumbing system that feeds the recent ascending magmas [e.g. Peltier et al. 2009b; Di Muro et al. 2014].

\section{Geological context}

The active PdF volcanic centre (Figure 1A) is located in the southeast quadrant of La Réunion Island (Indian Ocean) and has formed a $400 \mathrm{~m}$-high and $3 \mathrm{~km}-$ diameter Central Cone that grew within the Enclos Fouqué caldera (Figure 1B). Recent activity has mainly been restricted to effusive eruptions at this summit cone, along the NE and SE rift zones, and along a N120 trend [Bachèlery 1981; Michon et al. 2007a; b; 2015, Figure $1 \mathrm{~A}]$. Some historic and prehistoric eruptions have also taken place outside of these main structures. The summit is, at first sight, occupied by two coalescent craters: the small Bory crater (about 350 by 200 $\mathrm{m}$ ), and the larger Dolomieu crater (about 1100 by 800 $\mathrm{m})$ from which the rift zones diverge (Figure 1B). The Dolomieu crater has undergone several collapse events since the $18^{\text {th }}$ century [Villeneuve and Bachèlery 2006; Michon et al. 2009; 2013], the last one of which occurred during the major and well documented eruption of March-May 2007, which was accompanied by a $340 \mathrm{~m}$-deep collapse [e.g. Michon et al. 2007b; Staudacher et al. 2009].

The summit structure is even more complex with various pre-existing structures that strongly influence the dynamic as a whole, as highlighted by morphological studies [e.g. Carter et al. 2007; Michon et al. 2009; Derrien 2019], GNSS displacements and seismicity [e.g. Michon et al. 2008; Lengliné et al. 2016], as well as multi-temporal structure-from-motion studies [SfM, Derrien et al. 2015; Derrien 2019; Derrien et al. 2020]. The northern rim of Dolomieu following its col- 
A

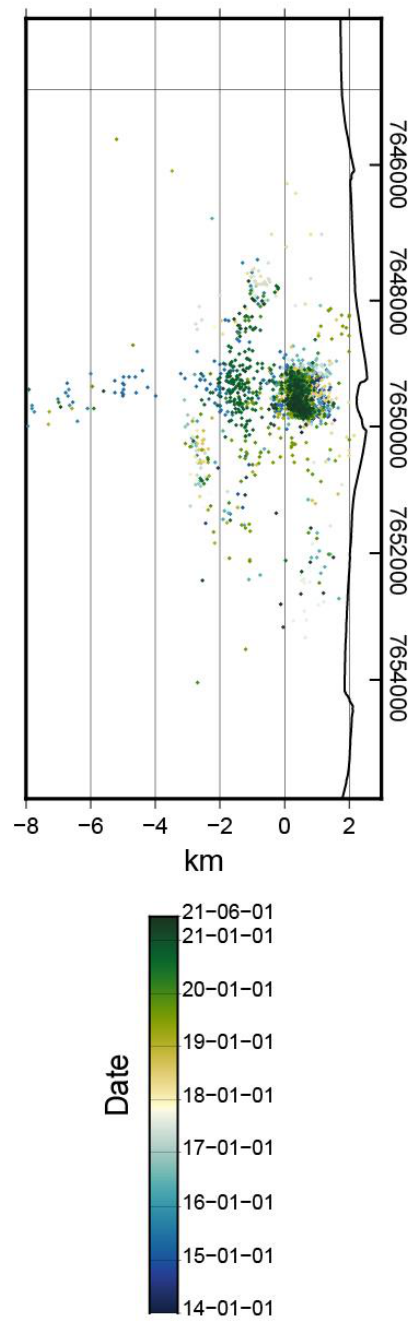

B

Easting (m, WGS84 UTM 40S)

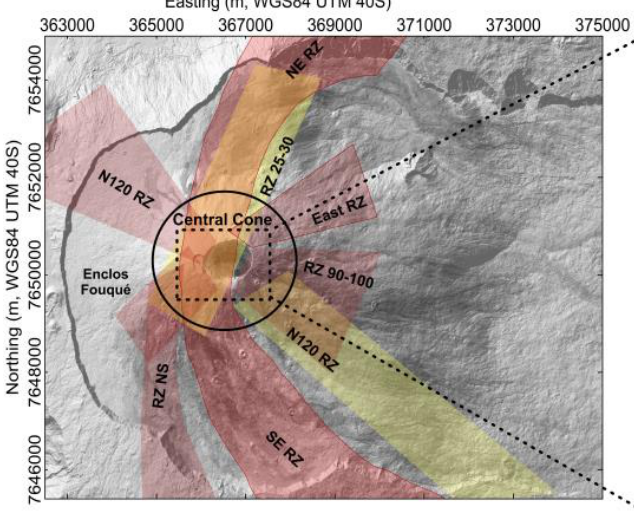

D

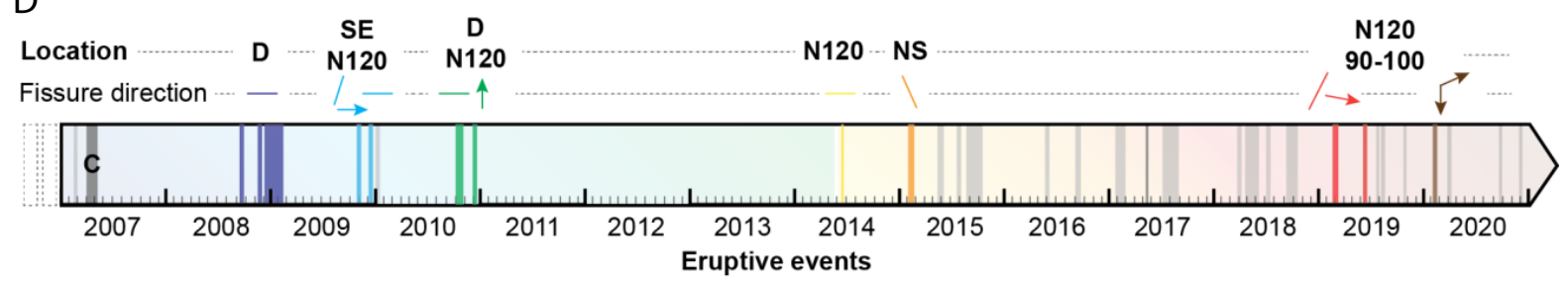

Figure 1: (Caption on next page.) 
Figure 1: (Previous page.) Location map. [A] Seismic events during the 2007-2020 period and interpreted W-E geological section of Piton de la Fournaise (after Gailler and Lénat [2012], Lénat et al. [2012a], and Michon et al. [2016]). Orange triangles locate the permanent seismic network inside and around the Enclos Fouqué caldera. The Brunhes-Matuyama interface locates the transition between the reverse and normal magnetic periods; [B] General context and location of the summit area from which the rift zones diverge (after Michon et al. [2016]). Red area: summit rift zones, from the orientation of recent dykes intruding the Central Cone (after Bonali et al. [2011]), yellow area: summit rift zones, from the statistical distribution of the scoria cones shape (1981-2006; after Michon et al. [2009]). The circle delineates the Central Cone. The black rectangle indicates the spatial extent shown in [C]. [C] Main structural features (pit craters) and lava flows at the summit area from 2008 to 2020 (OVPF database). The dotted lines delimit the Self-Potential (SP) maximum from Barde-Cabusson et al. [2012] associated with old pit-craters (2012). [D] Chronology of all eruptive and intrusive events (grey area) since the Dolomieu collapse in April 2007, highlighting (color bars) the summit eruptions (same color code as in [C]. The fissure directions and the flow orientations are shown (horizontal within Dolomieu crater, arrows highlight flow directions).

lapse has cut La Soufrière, a highly hydrothermally altered pit-crater that was considerably enlarged and dissected during the 2007 collapse. The north-western scarp of Dolomieu crater is marked by the presence of the Pre-Bory pit-crater [e.g. Bachèlery 1981; Lénat and Bachèlery 1990; Peltier et al. 2012]. Another interesting structure is an old pit-crater that opened up in 1791 at the southern edge of the present Dolomieu Crater, which has been renamed Petit Plateau and is now completely infilled (Figure 1C). Additionally, SelfPotential (SP) measurements carried out before the Dolomieu crater collapse in 2007 showed three SP maxima related to weak, more permeable, zones associated with these three older pit-crater structures (Petit Plateau, Pre-Bory, and La Soufrière) [Barde-Cabusson et al. 2012]. A fourth one has also been revealed to the east of Dolomieu (Figure 1C). These summit structures are located 500-1000 $\mathrm{m}$ to the east of, and above, the main subvertical magma feeding system "conduit" that extends between the two shallowest magma reservoirs at $7-8 \mathrm{~km}$ and $2.5 \pm 1 \mathrm{~km}$ depth below the surface [Battaglia et al. 2005; Peltier et al. 2009b; Prôno et al. 2009, ; Figure 1A], and which feeds the recent eruptions. All eruptive periods and associated phenomenon (magmatic and hydrothermal fluid transfer, collapses) have considerably and permanently deformed and fractured the summit area.

Here we focus on the evolution of the summit activity after the major eruption of March-May 2007, which is one of the most voluminous (estimation of $100-140 \times 10^{6} \mathrm{~m}^{3}$ by Staudacher et al. [2009] and $240 \times 10^{6} \mathrm{~m}^{3}$ by Roult et al. [2012]) and intense eruptions (output rate up to $100 \mathrm{~m}^{3} \mathrm{~s}^{-1} ; \sim 54 \mathrm{~m}^{3} \mathrm{~s}^{-1}$ on average [Staudacher et al. 2009]) at PdF for more than a century. This exceptional eruptive activity [e.g. Michon et al. 2007b; Urai et al. 2007; Staudacher et al. 2009] led to: 1) the collapse of the Dolomieu crater (320-340 m in depth; Figure 1C); and 2) major stress changes in the volcanic edifice [Roult et al. 2012] that have strongly influenced the location of further eruptions so far [e.g. Peltier et al. 2010; 2018].

Following this major event, several small-volume eruptions occurred within the crater and near the sum- mit from 2008 to 2010 [Roult et al. 2012]. A new period of activity began in June 2014, after 42 months of quiescence [e.g. Lengliné et al. 2016; Peltier et al. 2016]. The multi-temporal SfM study [Derrien 2019] and GNSS data [Peltier et al. 2010] have shown significant ground deformation since 2007, just after the Dolomieu collapse. Overall deflation was recorded from 2007 to 2010, with short periods of inflation occurring only during the pre-eruptive and eruptive phases [Peltier et al. 2010]. Slow deflation continued during the rest period from 2010 to 2014, when overall inflation started again. This latter has evolved in steps since 2016, implying a discontinuous magma accumulation below the summit area [Peltier et al. 2018].

This study includes the summit and near-summit eruptions from March-April 2007 up to December 2020, when the UAV survey was carried out. During this period, 12 eruptions (i.e. about $37.5 \%$ of the overall eruptions at the scale of the edifice during the considered period; Figure 1D) and about 55 eruptive fissures opened up in the summit part of the Central Cone, most of them within 1) the Dolomieu crater before 2014, and 2) along the rift zones (RZ) since 2014 (Figure 1C and 1D).

\section{Methodology}

\subsection{UAV sensors and data acquisition}

UAVs have only recently come into use for geophysical surveying [Antoine et al. 2020; James et al. 2020] with, among others, the example of high resolution digital elevation models (DEM) [Derrien 2019], IR mapping [Wessels et al. 2013], and also magnetic imaging [Catalán et al. 2014]. We performed a homogeneous thermal IR coverage of the entire summit area of PdF, as well as for high-resolution magnetic anomaly mapping all around the Dolomieu-Bory craters. While high-resolution thermal IR measurements from UAVs are a well-proven method for detecting the various scales and temporal evolution of temperature anomalies (magmatic, hydrothermal, and fumarole mapping [e.g. Calvari et al. 2003; James et al. 2020]), UAV mag- 
A

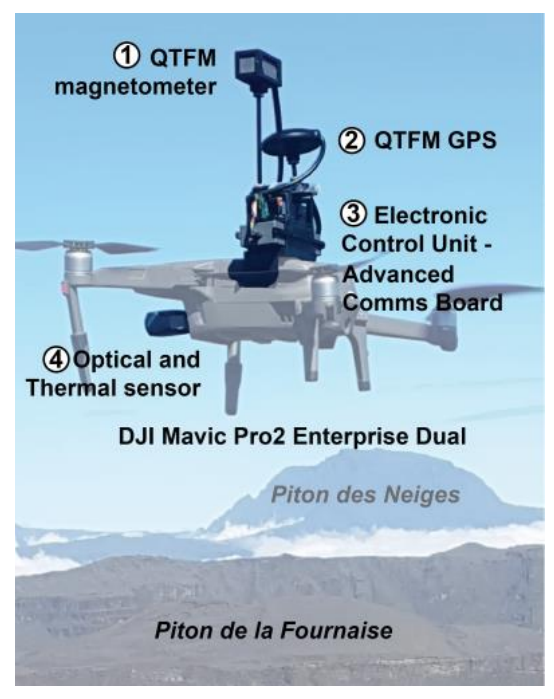

B

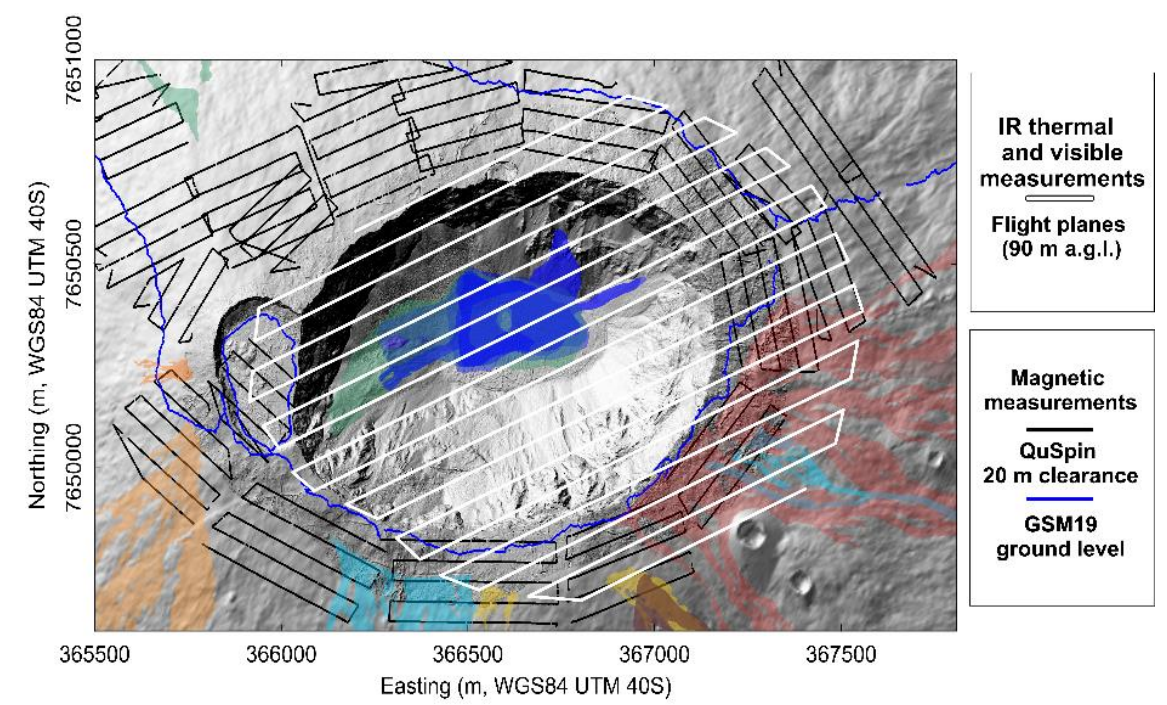

Figure 2: The 2020 geophysical survey. [A] QuSpin Total Field (QTFM) magnetic sensor, mounted on a DJI Mavic Pro2 Enterprise Dual with optical and thermal sensors. [B] Location of the UAV thermal IR (white) and magnetic measurement (black) profiles, superimposed onto the lava flows emitted close to the summit shown in Figure 1C.

netic sensors are also now fully operational and could considerably contribute to the efficient detection of magnetic signals related to volcanic activity [Catalán et al. 2014; Gailler et al. 2021].

We used a high-sensitivity and high-performance scalar magnetometer, the QuSpin Total-Field Magnetometer (QTFM; Figure 2A), based on an optically pumped rubidium sensor. It is associated with an Electronic Control Unit (ECU), an Advanced Communication Board (ACB) and a GNSS receiver (1 s acquisition rate). It provides magnetic field measurements that can resolve very small temporal changes $(<10 \mathrm{nT})$. This is higher than common aeromagnetic survey using both fluxgate and scalar magnetometers that usually provide accuracy lower than $2 \mathrm{nT}$ [Coyle et al. 2014; Gavazzi et al. 2019; Kaub et al. 2021].

In our case, the absolute accuracy will be quantified using the differences at the crossing point of repeated profiles [Nabighian et al. 2005]; this will be discussed hereafter. Gailler et al. [2021] confirmed the high sensitivity of the QTFM sensor for our purpose; in particular for reaching the high amplitudes of the magnetic signal commonly recorded in volcanic contexts without any post-flight calibration, which is particularly relevant for near-real-time interpretation of the data. The total overall weight (of less than $200 \mathrm{~g}$ ) allows the sensor to be implemented on a very small UAV, the DJI ${ }^{\circledR}$ Mavic Pro2 Dual, in order to ensure rapid and efficient deployment in the field. Another advantage of this craft is that it is equipped with a double thermal and optical sensor (Figure 2A). The optical part uses a $1 / 2$ inch CMOS sensor, whose display uses 48 megapixels. The thermal sensor is a FLIR Letpon radiometric thermal sensor that provides simple and rapid infrared vision. It natively captures images with a resolution of
$160 \times 120$ pixels but automatically enhances the image to $640 \times 360$ pixels with its built-in software.

In terms of data acquisition, the thermal IR and visible imaging were simultaneously acquired at a constant altitude of $90 \mathrm{~m}$ above the take-off area (2589 $\mathrm{m}$ asl) with a $65 \mathrm{~m}$ spacing between profiles. Magnetic measurements were performed at an altitude of $20 \mathrm{~m}$ above topography, using UgCS control software with a $50 \mathrm{~m}$ spacing between profiles. Note that coupled magnetic measurements were performed at the ground surface in order to check the quality of the UAV's magnetic measurements (Figure 2B).

Depending on the payload, the flight duration averaged between 10 and $20 \mathrm{~min}$, with or without the magnetic sensor respectively. In this study, we look at 17 magnetic flights around the Dolomieu-Bory craters and the overall visible and thermal mapping of the latter was carried out over three periods in order to cover the entire summit area.

This high resolution survey was designed to: 1) provide a new high resolution DEM at the scale of the Dolomieu crater (Figure 1C and Figure 2B); 2) acquire a thermal IR-visible map of the summit area; and 3) image the main magnetic anomalies around the latter, at a resolution not previously achieved. The main goal of our study was to use the new data and images to investigate the thermal state of the PdF active summit zone, and to improve our knowledge of the associated fracturing system and weakened zones since the Dolomieu crater collapse in 2007 , i.e. identify the most active structures at the present time that could develop into preferential magma pathways and instabilities at depth. 


\subsection{Data treatment}

A total of 2444 IR and visible images was acquired for the study area, and has been treated with Agisoft Metashape Professional to derive the final orthophotography (Figure 3A) and the DEM (Figure 2B) at a resolution of $17 \mathrm{~cm}$, and the IR model (Figure 3B) at a resolution of $0.35 \mathrm{~m}$. Since our thermal imaging was performed at 06:00, it should be noted that solar radiation was not completely avoided and that some temperature anomalies are most likely due to differential heating of the ground. Therefore, an aspect correction was performed, following which the mainly radial anomalies observed within the Dolomieu crater are clearly highlighted (Figure 3B).

Magnetic measurements were processed as follows. An intersection adjustment was carried out at profile crossings, first for each series of flights, and then between sets of flights. A total of 222 crossing points were considered for the overall survey, with a mean difference value of $-1.7 \mathrm{nT}$ attesting to the good quality of the data and a high consistency between all flights all along the survey. Even if the standard deviation is high (i.e. $40 \mathrm{nT}$ ), it remains accurate enough when considering the very high amplitude anomalies (in the range of thousands of nT) we target in volcanic contexts.

The comparison with the ground measurements, extrapolated upwards to $20 \mathrm{~m}$, has been performed at all crossing points with the UAV measurements, with values lower than a few $\mathrm{nT}$ in average, confirming the reliability of the UAV measurements and their good resolution. Given the very low diurnal variation, i.e. a few 10 s of $\mathrm{nT}$ compared to spatial variations in the order of $5000 \mathrm{nT}$ observed in this type of volcanic context [Zurek and Williams-Jones 2013; Gailler et al. 2021], no diurnal correction was made. The data were then reduced using the magnetic field intensity predicted by the International Geomagnetic Reference Model version 13 [IGRF; Finlay et al. 2010] to compute the magnetic anomaly at the time of the survey (Figure 3C). Following this, the data were gridded separately, flightby-flight, using the minimum curvature method with a grid spacing of $20 \mathrm{~m}$. All datasets were then merged using the Oasis Montaj stitching subroutine (Grid Knitting, Geosoft 2013) to improve fit and smooth the overlap between all surveys. More details on the method are provided in Gailler et al. [2021].

The last transformation to be applied was a reduction to the pole (RTP) to significantly reduce the dipolar appearance of the anomalies and offset them to their source [Baranov 1957]. Here we used the direction of the induced magnetization vector that is collinear with the ambient field (magnetic field vector in La Réunion at the time of the survey: declination $-19^{\circ}$; inclination $-54^{\circ}$; Figure 3D).

\section{Discussion}

\subsection{Main results}

Being composed of a pile of permeable (scoria sequences) and dense layers (lava flows) [e.g. Peltier et al. 2012], PdF is marked by a high horizontal permeability [Antoine et al. 2017] combined with steep slopes that trigger intense air convection [Genthon et al. 1990]. The associated temperature anomalies are therefore difficult to interpret. The thermal image acquired for the Dolomieu crater in March 2008 [Derrien et al. 2020] displays a thermal ring mainly associated with fumarolic activity [Staudacher 2010] and hydrothermal fluid circulation within the crater. This image of the temporal and spatial evolution of the thermal structures within the Dolomieu crater following its collapse in 2007 has also shown the development of outer ring faults [Michon et al. 2007b; 2008; Derrien et al. 2020]. This is consistent with our observations, with two main concentric high temperature zones clearly highlighted around the Dolomieu crater $\left(>30^{\circ} \mathrm{C}\right.$; Figure $\left.3 \mathrm{~B}\right)$ in areas where several fissures are well imaged on the ground surface (Figure 3A): 1) to the east where some of the 2019 fissures opened in February and June, and 2) to the south of the Dolomieu crater, west of Petit Plateau. The areas of Bory crater, Petit Plateau, and La Soufrière do not show any significant temperature anomalies. All of these features are discussed in the following section.

The overall magnetic anomalies map is firstly used to delineate the main positive and negative signal areas, associated with, respectively 1) non-anomalous, highly magnetized stable geological structures, and 2) low magnetized zones that may act as fluid pathways or weakened areas at depth. At the first order, highly magnetized areas $(>2500 \mathrm{nT})$ are dissected by three primary negative or very low anomalies $(<1500 \mathrm{nT})$ clearly shown along the NE and SE rift zones, and along the N120-Eastern Flank rift zone. Due to the long wavelength of the imaged negative anomalies, the main dipolar anomalies should have their sources within the shallow pile of Piton de la Fournaise lava flows and therefore cannot be caused by reversely magnetized rocks since the age of the volcano (about $0.54 \mathrm{Ma}$ [Bachèlery and Mairine 1990]) is too far from the 0.78 Ma Brunhes-Matuyama reversal (Figure 1A). Accordingly, such anomalies should be interpreted as the presence of weakly magnetized rocks in an environment of typically highly magnetized volcanic rocks.

\subsection{Qualitative interpretation: highlighting active ar- eas}

In this section we propose a first order qualitative joint interpretation of the main temperature and magnetic anomalies. We have previously demonstrated strong correlations between the two types of anomalies in specific areas around the Dolomieu crater, with a link 

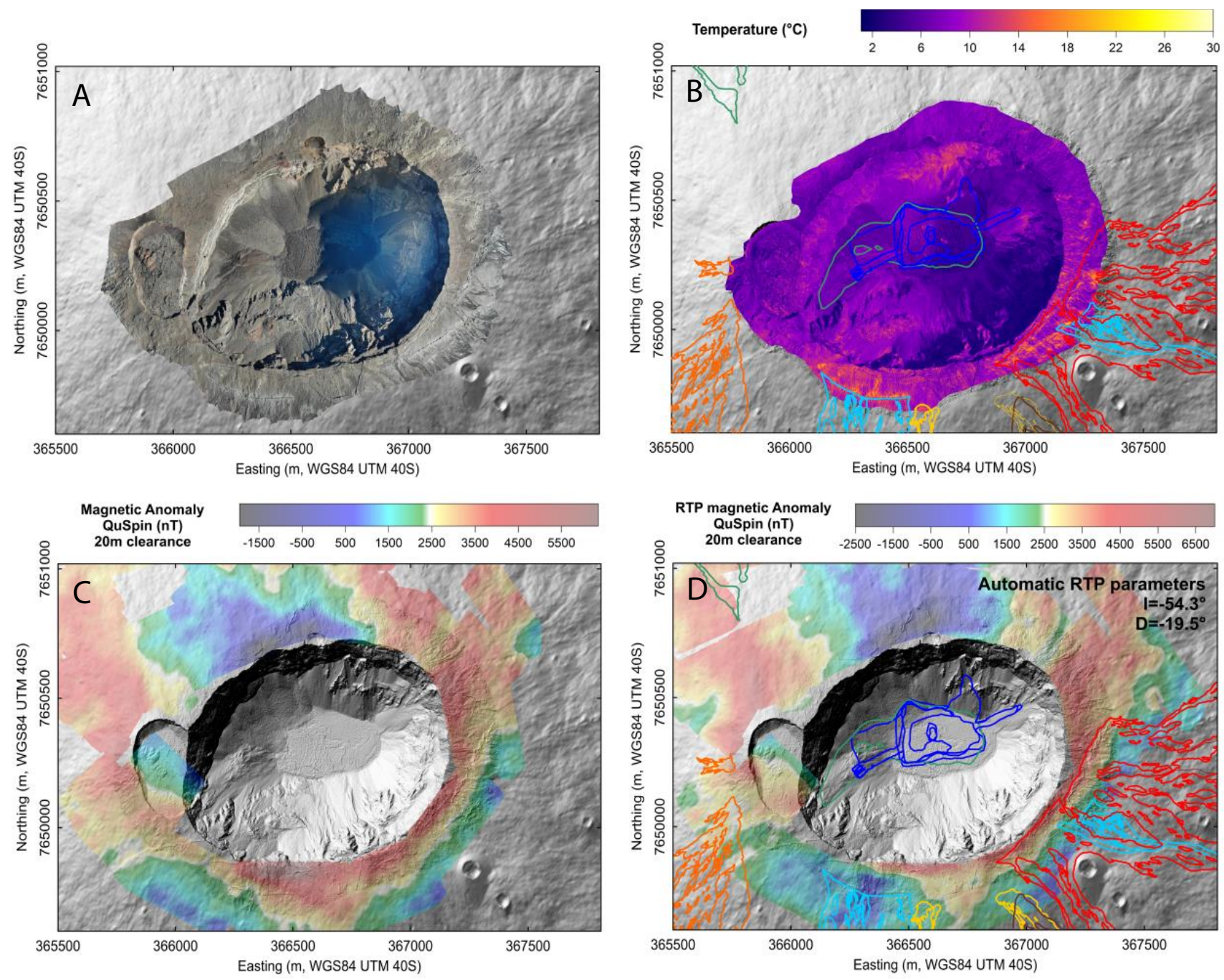

Figure 3: Multi-method UAV imaging of the summit area of Piton de la Fournaise. [A] Orthophoto. [B] Thermal IR image corrected for ground heating. [C] Maps of the magnetic anomalies, and [D] Reduced to the pole (RTP) magnetic anomalies. For insets $[B]$ and [D], the color code for the contours of the lava flows is the same as in Figure 1.

between 1) low magnetization and high temperature anomalies, 2) low magnetization and no temperature anomalies, and 3) high magnetization and no thermal anomalies. We discuss here the implication of such observations on structures that remain active at depth.

1) The combination of low magnetization with high temperature anomalies is well interpreted in terms of active areas that have been strongly intruded by magma since 2007 . The first one is observed to the south of Dolomieu crater along the SE RZ (Figure 4), mainly associated with the December 2009 eruptive fissure and more locally with the June 2014 eruption that occurred after a long rest period. A similar trend is observed when moving eastwards, in the upper part of the well-studied Eastern Flank of PdF (Figure 4). This is not surprising because this area is highly dissected by radial and concentric fractures [Bachèlery 1981; Labazuy 1996; Merle and Lénat 2003], a trend that has been significantly increased with the recent activity in this sector and the strong deformation associated with and since the Dolomieu crater collapse in 2007 [e.g. Froger et al. 2015a; b; Tridon et al. 2016]. These fractures, well visible on the orthophotographs and thermal anomaly map, are undoubtedly preferential pathways for intrusions, as confirmed by the 2019 eruptions that occurred in February and June in this zone (Figure 4). Note that along the Eastern Flank, the main low amplitude magnetic gradient is observed downslope, while the temperature anomalies are located closer to the summit rims, following the eruptive fissures toward the east, along the N120 RZ (Figure 4). On unaltered surface areas, such magnetic anomalies could be linked to the effects of recent flows at the surface, but also to the presence of strong mechanical heterogeneities at depth, giving the long wavelength of the magnetic signal. This is consistent 


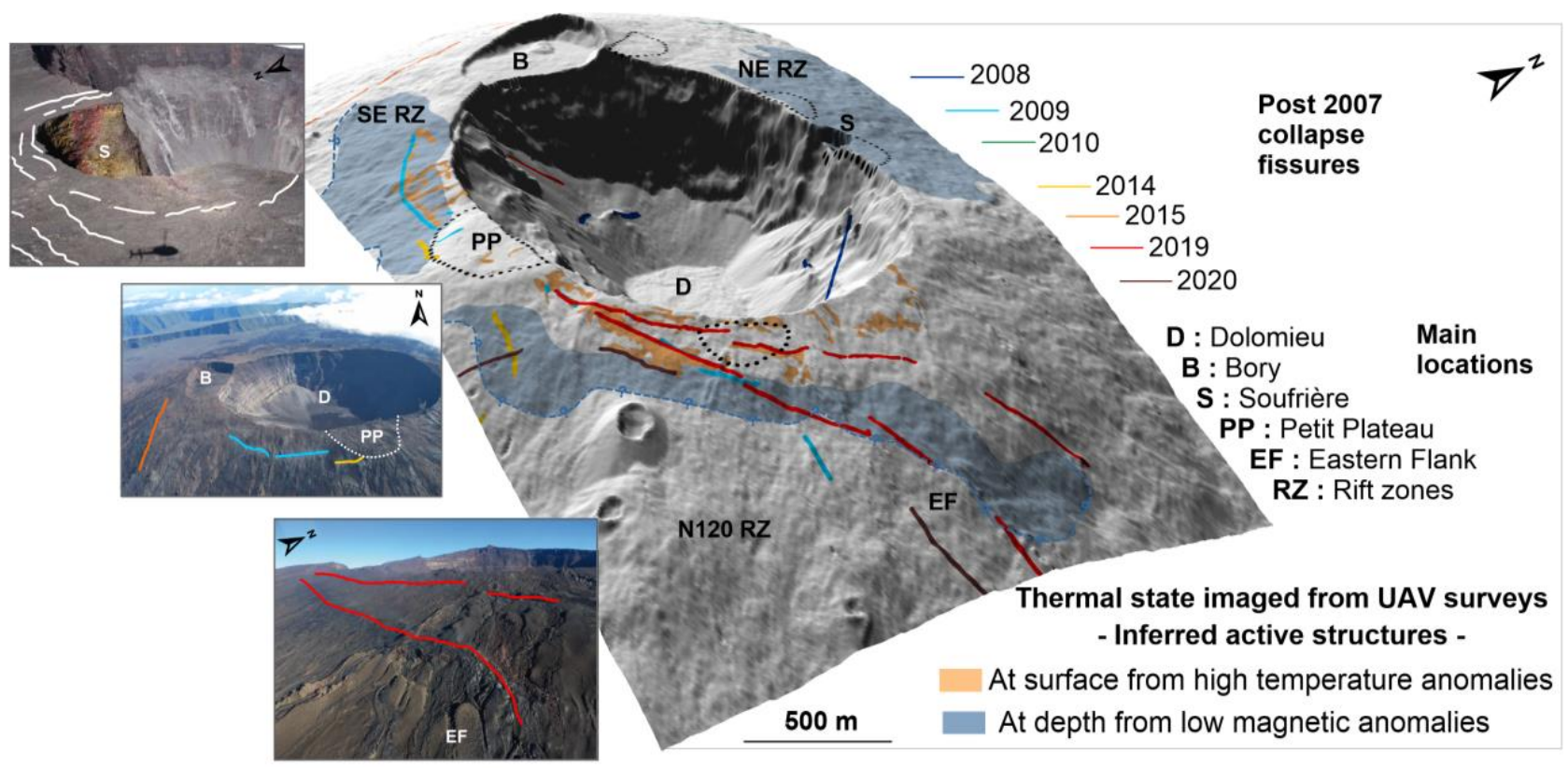

Figure 4: Combined interpretation from IR temperature and magnetic anomalies imaging. Fissures location from OVPF database (same color code as lava flows in Figure 1). Associated aerial field photos from OVPF-IPGP-Imaz Press.

with the eastern direction of the sliding motion [e.g. Brenguier et al. 2012; Peltier et al. 2015] (and maybe the sliding plane) of this flank in response to deformation and eruptive activity [Froger et al. 2015a; b; Tridon et al. 2016], and could be interpreted in terms of a zone of greater mechanical weakness at depth [Dumont et al. 2019].

2) The combination of low magnetization with the absence of any temperature anomaly at the surface is observed at La Soufrière pit-crater to the north of Dolomieu crater (Figure 4). Regarding the geological context, it could be interpreted in terms of a highly altered, fractured and permeable area, as confirmed by the high amplitude positive SP and conductive anomalies [Barde-Cabusson et al. 2012; Dumont et al. 2019] associated with strong hydrothermal alteration, and a decrease in magnetization and resistivity [Dumont et al. 2019]. This area has not been intruded by magma since 2007. Despite its highly altered state, there is no evidence of preferential paths for magmatic fluids to reach the surface. It could be interpreted in terms of a highly stable state of the hydrothermal system and is consistent with the lack of eruptive activity in the northern part of the summit area since 2008. Nevertheless, such weaknesses and thermally active areas could, in the future, be considered as preferential pathways for the transfer of shallow hydrothermal and magmatic fluids during further activity, representing a strong hazard in terms of phreatomagmatic or phreatic eruptions [Villeneuve and Bachèlery 2006]. Conversely, several areas appear non-anomalous, being highly magnetized, cold, and stable. This is especially the case of the Petit Plateau pit-crater to the south (Figure 4), which is however associated with a mainly positive SP anomaly since it remains highly fractured [Michon et al. 2009; Barde-Cabusson et al. 2012]. This is also, more surprisingly, the case to the west of Bory crater, an area that was in fact affected by an eruption in February 2015 but does not present any significant SP anomaly [BardeCabusson et al. 2012].

3) Two areas could be considered as non-anomalous, cold and highly magnetized. The first one coincides with Petit Plateau, which is a highly fractured pit-crater (Figure 4). A similar trend is also observed in the southwest of the study area, south of the Bory crater, in an area that was nevertheless intruded in February 2015 (Figure 4). These areas are probably more stable from a thermal point of view, being less affected by magmatic and/or hydrothermal processes during the last decades.

The differences in the extent of the two types of anomalies could be interpreted in terms of the different depths of anomalous structures. Temperature anomalies are closely related to summit intrusions and probably associated with shallow active structures, whereas magnetic anomalies extend considerably further down and are more likely attributed to deeper active structures. 

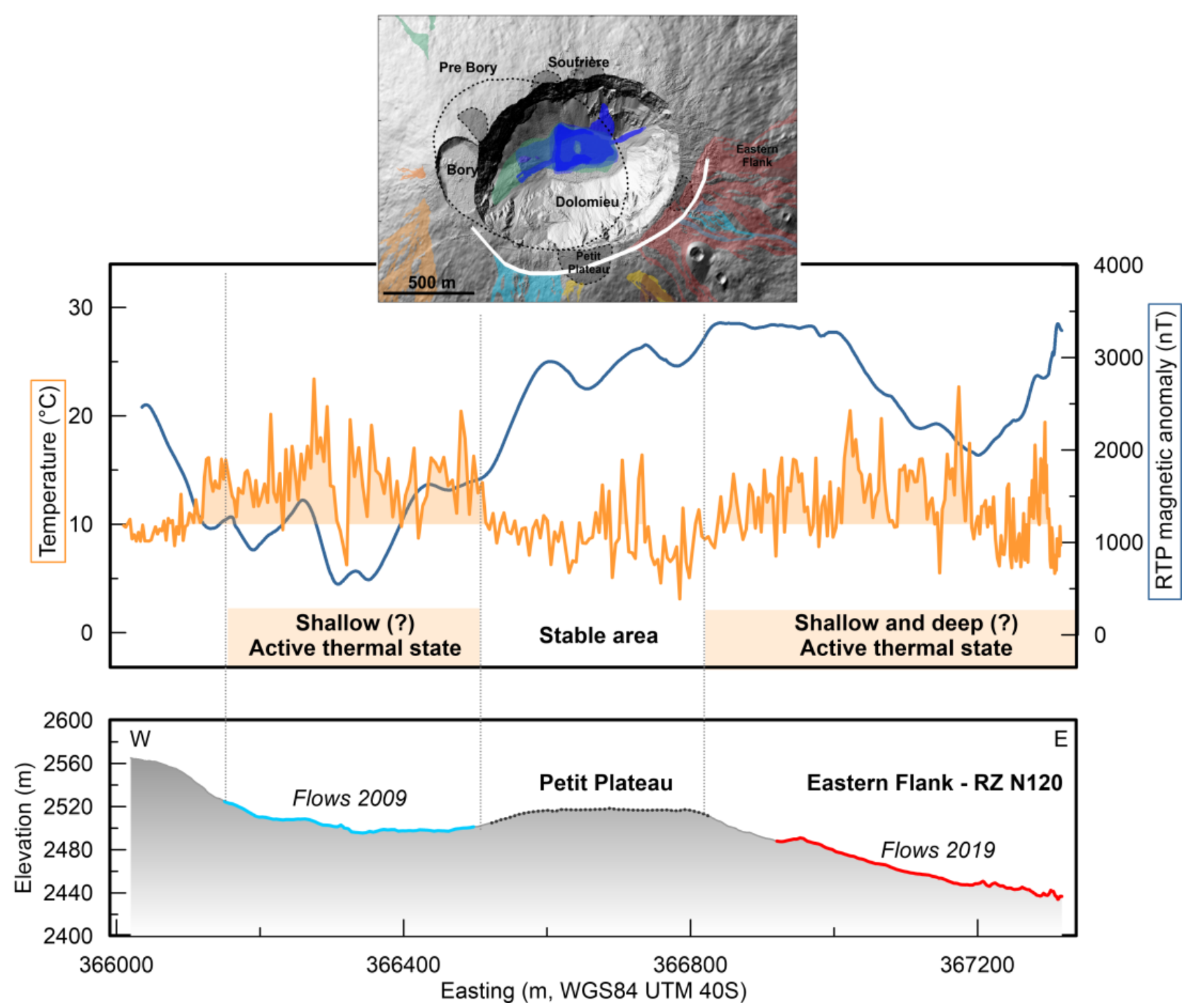

Figure 5: Detailed comparison between IR temperature and magnetic anomalies along a main profile, to the south of the Dolomieu crater (located in white on top ; the color code for the lava flows is the same as in Figure 1), highlighting the main thermally active and stable areas.

\section{Conclusions}

Using UAVs is a considerable advance that makes volcano monitoring more efficient (homogeneous cover, rapid and safe usage on otherwise inaccessible areas; [e.g. Antoine et al. 2020; Gailler et al. 2021]), providing data in $3 \mathrm{D}$, and at different scales. To investigate the potential of geophysical methods for imaging active volcano-tectonic structures, we coupled highresolution UAV magnetic measurements with IR thermal surveys over the summit area of PdF.

We focused on eruptive activity following the 2007 collapse of the Dolomieu crater and showed that low magnetization anomalies are well correlated with high temperature signals in areas that have been intruded by magma during this period, to the south of the Bory and Dolomieu craters for the 2007-2014 period, and to the east, along the N120 RZ-Eastern Flank, for the 2014 to the present period (Figure 5). As shown by Dumont et al. [2019], these observations are consistent with the main intrusive paths radiating from the Central Cone through the NE-SE and N120 RZ. These anomalous areas and their orientation provide more information on the distribution of weakness zones, in order to better evaluate the risk of eruptions (preferential pathways for magma migration at depth) or partial landslides, especially along the Eastern Flank (mechanical heterogeneities along the sliding plane; Figure 5). In this particular area, our results are consistent with the weakness zone imaged by the Airborne Electromagnetic (AEM) survey, where a main conductive layer that follows the topography is imaged at a depth of about $500 \mathrm{~m}$ below the surface [Dumont et al. 2019].

To conclude, the comparison between the temper- 
ature and magnetic anomalies imaged in November 2020 at the scale of the PdF summit highlights zones of major thermal activity (along the SE RZ, N120 RZ and Eastern Flank; Figure 5), areas of alteration and high permeability (La Soufrière), and low mechanical resistance (Eastern Flank sliding plane). The temperature anomalies are predominantly limited to eruptive fissures opened at the surface and allow better constraint of the spatial extent of the anomalies at shallow depth, between the plumbing system and associated recent fissures. The low magnetic anomalies highlight the active thermal state at greater depth, and its connection with the surface. Therefore, these results open new perspectives in the study of spatiotemporal changes in magmatic, hydrothermal, and mechanical variations or alteration processes within volcanic edifices. The consistency between all the approaches confirms the potential of combining IR with high-resolution magnetic surveys using UAVs, and the interest of regularly repeated surveys to monitor the dynamics of the overall volcanic system at even higher resolution, for example at a metric scale. Such repeated measurements would improve our understanding, in $4 \mathrm{D}$, of the rate of change of such parameters (temperature and magnetization) by quantifying their spatio-temporal evolution, which is a powerful tool in imaging volcanic systems at various scales. Mapping the evolution of the thermal state of the edifice, with a new combination of those parameters will be used to better identify the main weakness zones that could be interpreted in terms of preferential pathways for fluid transfer and mechanical heterogeneities. Future research will be carried out using larger payload UAVs in order to combine magnetic measurements with higher resolution IR cameras, and to enable combined high-resolution 3D models to be performed.

\section{Acknowledgements}

This study was funded on behalf by a CNES project and by the Laboratory of Excellence ClerVolc. This research was led in the frame of the EUROVOLC project. We are grateful to the staff of the Observatoire Volcanologique du Piton de la Fournaise from Institut de Physique du Globe de Paris (OVPF-IPGP), and Raphaël Antoine (Cerema) for their support all along the field survey and fruitful discussions. We also warmly acknowledge the Parc National de la Réunion and InAirTech. We are grateful to the two anonymous reviewers for their very constructive reviews that improved this article. This is Laboratory of Excellence ClerVolc contribution number 495.

\section{Author contributions}

L.G., P.L., E.R., conceived, planned and carried out the experiments. E.R. designed the mounting and implementation of the sensor on the drone. A.P. was involved in planning and helped supervise the project at OVPF.
A.P and V.F. supervised the analysis of additional data from the OVPF. All authors discussed the results and commented on the manuscript.

\section{Data aVailability}

The data presented in this study are available on request from the corresponding author.

\section{COPYRIGHT NOTICE}

(C) The Author(s) 2022. This article is distributed under the terms of the Creative Commons Attribution 4.0 International License, which permits unrestricted use, distribution, tand reproduction in any medium, provided you give appropriate credit to the original author(s) and the source, provide a link to the Creative Commons license, and indicate if changes were made.

\section{REFERENCES}

Antoine, R., A. Finizola, T. Lopez, D. Baratoux, M. Rabinowicz, E. Delcher, F. R. Fontaine, F. J. Fontaine, G. Saracco, P. Bachèlery, and T. Staudacher (2017). "Electric potential anomaly induced by humid air convection within Piton de La Fournaise volcano, La Réunion Island". Geothermics 65, pp. 81-98. DoI: 10.1016/j.geothermics. 2016.01.003.

Antoine, R., T. Lopez, M. Tanguy, C. Lissak, L. Gailler, P. Labazuy, and C. Fauchard (2020). "Geoscientists in the Sky: Unmanned Aerial Vehicles Responding to Geohazards". Surveys in Geophysics 41(6), pp. 12851321. DoI: $10.1007 / \mathrm{s} 10712-020-09611-7$.

Araña, V., A. G. Camacho, A. Garcia, F. G. Montesinos, I. Blanco, R. Vieira, and A. Felpeto (2000). "Internal structure of Tenerife (Canary Islands) based on gravity, aeromagnetic and volcanological data". Journal of Volcanology and Geothermal Research 103(1-4), pp. 43-64. DoI: 10.1016/s0377-0273(00) $00215-8$.

Bachèlery, P. (1981). "Le Piton de la Fournaise (Ile de la Réunion): étude volcanologique, structurale et pétrologique”. PhD thesis. Université Blaise Pascal Clermont-Ferrand.

Bachèlery, P. and P. Mairine (1990). "Evolution volcano-structurale du Piton de la Fournaise depuis $0.53 \mathrm{Ma}$. Le Volcanisme de La Réunion, Monographie. Ed. by J.-F. Lénat. Centre de Recherches Volcanologiques, Clermont-Ferrand, pp. 213-242.

Baranov, V. (1957). "A new method for interpretation of aeromagnetic maps: pseudo-gravimetric anomalies". Geophysics 22(2), pp. 359-382. DoI: 10.1190/1. 1438369.

Barde-Cabusson, S., A. Finizola, A. Peltier, M. Chaput, N. Taquet, S. Dumont, Z. Duputel, A. Guy, L. Mathieu, S. Saumet, F. Sorbadère, and M. Vieille (2012). "Structural control of collapse events inferred by 
self-potential mapping on the Piton de la Fournaise volcano (La Réunion Island)". Journal of Volcanology and Geothermal Research 209-210, pp. 9-18. DoI: 10 . 1016/j . jvolgeores. 2011.09.014.

Battaglia, J., K. Aki, and V. Ferrazzini (2005). "Location of tremor sources and estimation of lava output using tremor source amplitude on the Piton de la Fournaise volcano: 1. Location of tremor sources". Journal of Volcanology and Geothermal Research 147(3-4), pp. 268-290. DOI: $10.1016 / \mathrm{j}$. jvolgeores . 2005.04 . 005.

Blakely, R. J. (1995). Potential Theory in Gravity and Magnetic Applications. Cambridge University Press. Dor: $10.1017 /$ cbo9780511549816.

Bonali, F. L., C. Corazzato, and A. Tibaldi (2011). "Identifying rift zones on volcanoes: an example from La Réunion island, Indian Ocean". Bulletin of Volcanology 73(3), pp. 347-366. DoI: 10.1007 / s00445-010๑416- 1.

Boudoire, G., Y.-A. Brugier, A. Di Muro, G. Wörner, I. Arienzo, N. Metrich, V. Zanon, N. Braukmüller, A. Kronz, Y. Le Moigne, and L. Michon (2019). "Eruptive Activity on the Western Flank of Piton de la Fournaise (La Réunion Island, Indian Ocean): Insights on Magma Transfer, Storage and Evolution at an Oceanic Volcanic Island". Journal of Petrology 60(9), pp. 17171752. Dor: $10.1093 /$ petrology/egz 045 .

Bouligand, C., S. Hurwitz, J. Vandemeulebrouck, S. Byrdina, M. A. Kass, and J. L. Lewicki (2019). "Heat and Mass Transport in a Vapor-Dominated Hydrothermal Area in Yellowstone National Park, USA: Inferences From Magnetic, Electrical, Electromagnetic, Subsurface Temperature, and Diffuse CO2 Flux Measurements". Journal of Geophysical Research: Solid Earth 124(1), pp. 291-309. DoI: 10.1029/2018jb016202.

Bouligand, C., M. A. Tivey, C. A. Finn, L. A. Morgan, W. C. P. Shanks, and R. A. Sohn (2020). "Geological and Thermal Control of the Hydrothermal System in Northern Yellowstone Lake: Inferences From High-Resolution Magnetic Surveys". Journal of Geophysical Research: Solid Earth 125(9). Dor: 10.1029/ 2020jb019743.

Brenguier, F., P. Kowalski, T. Staudacher, V. Ferrazzini, F. Lauret, P. Boissier, P. Catherine, A. Lemarchand, C. Pequegnat, O. Meric, C. Pardo, A. Peltier, S. Tait, N. M. Shapiro, M. Campillo, and A. Di Muro (2012). "First Results from the UnderVolc High Resolution Seismic and GPS Network Deployed on Piton de la Fournaise Volcano". Seismological Research Letters 83(1), pp. 97-102. DoI: 10.1785/gssrl.83.1.97.

Calvari, S., M. Neri, and H. Pinkerton (2003). "Effusion rate estimations during the 1999 summit eruption on Mount Etna, and growth of two distinct lava flow fields". Journal of Volcanology and Geothermal Research 119(1-4), pp. 107-123. DOI: 10.1016/s0377$0273(02) 00308-6$.

Carter, A., B. van Wyk de Vries, K. Kelfoun, P. Bachèlery, and P. Briole (2007). "Pits, rifts and slumps: the summit structure of Piton de la Fournaise". Bulletin of Volcanology 69(7), pp. 741-756. DOI: $10.1007 / \mathrm{s} 00445-006-0103-4$.

Catalán, M., Y. M. Martos, J. Galindo-Zaldıvar, and M. Funaki (2014). "Monitoring the evolution of Deception Island volcano from magnetic anomaly data (South Shetland Islands, Antarctica)". Global and Planetary Change 123, pp. 199-212. Dor: $10.1016 /$ j.gloplacha. 2014.07.018.

Chevrel, M. O., M. Favalli, N. Villeneuve, A. J. L. Harris, A. Fornaciai, N. Richter, A. Derrien, P. Boissier, A. Di Muro, and A. Peltier (2021). "Lava flow hazard map of Piton de la Fournaise volcano". Natural Hazards and Earth System Sciences 21(8), pp. 2355-2377. Dor: 10.5194/nhess-21-2355-2021.

Coyle, M., R. Dumont, P. Keating, F. Kiss, and W. Miles (2014). Geological Survey of Canada aeromagnetic surveys: design, quality assurance, and data dissemination. Tech. rep. Natural Resources Canada. https://doi. org/10.4095/295088.

Derrien, A. (2019). “Application of photogrammetry to the geomorphologic mapping and the investigation of the structural dynamics of Piton de la Fournaise volcano, La Réunion". PhD thesis. Université de Paris. https://u-paris.fr/theses/detail-dunethese $/$ ?id_these $=4004$.

Derrien, A., A. Peltier, N. Villeneuve, and T. Staudacher (2020). "The 2007 caldera collapse at Piton de la Fournaise: new insights from multi-temporal structure-from-motion". Volcanica 3(1), pp. 55-65. DoI: $10.30909 /$ vol.03.01.5565.

Derrien, A., N. Villeneuve, A. Peltier, and F. Beauducel (2015). "Retrieving 65 years of volcano summit deformation from multitemporal structure from motion: The case of Piton de la Fournaise (La Réunion Island)". Geophysical Research Letters 42(17), pp. 69596966. DoI: $10.1002 / 2015 \mathrm{gl} 064820$.

Di Muro, A., N. Metrich, D. Vergani, M. Rosi, P. Armienti, T. Fougeroux, E. Deloule, I. Arienzo, and L. Civetta (2014). "The Shallow Plumbing System of Piton de la Fournaise Volcano (La Reunion Island, Indian Ocean) Revealed by the Major 2007 Caldera-Forming Eruption". Journal of Petrology 55(7), pp. 1287-1315. DoI: 10 . 1093 / petrology / egue25.

Dumont, M., A. Peltier, E. Roblin, P.-A. Reninger, S. Barde-Cabusson, A. Finizola, and V. Ferrazzini (2019). "Imagery of internal structure and destabilization features of active volcano by 3D high resolution airborne electromagnetism". Scientific Reports 9(1). DOI: $10.1038 / \mathrm{s} 41598-019-54415-4$.

Finlay, C. C., S. Maus, C. D. Beggan, T. N. Bondar, A. Chambodut, T. A. Chernova, A. Chulliat, V. P. Golovkov, B. Hamilton, M. Hamoudi, R. Holme, G. Hulot, W. Kuang, B. Langlais, V. Lesur, F. J. Lowes, H. Lühr, S. Macmillan, M. Mandea, S. McLean, C. Manoj, M. Menvielle, I. Michaelis, N. Olsen, J. Rauberg, M. Rother, T. J. Sabaka, A. Tangborn, L. 
Tøffner-Clausen, E. Thébault, A. W. P. Thomson, I. Wardinski, Z. Wei, and T. I. Zvereva (2010). "International Geomagnetic Reference Field: the eleventh generation". Geophysical Journal International 183(3), pp. 1216-1230. DOI: $10.1111 /$ j . 1365-246x . 2010 . $04804 . x$.

Finn, C. A., M. Deszcz-Pan, J. L. Ball, B. J. Bloss, and B. J. Minsley (2018). "Three-dimensional geophysical mapping of shallow water saturated altered rocks at Mount Baker, Washington: Implications for slope stability". Journal of Volcanology and Geothermal Research 357, pp. 261-275. Dor: 10.1016/j . jvolgeores. 2018.04 .013$.

Froger, J.-L., V. Cayol, and V. Famin (2015a). "The March-April 2007 Eruptions of Piton de la Fournaise as Recorded by Interferometric Data". Active Volcanoes of the Southwest Indian Ocean. Springer Berlin Heidelberg, pp. 271-286. DoI: 10.1007/978-3-64231395- 9 _16.

Froger, J.-L., V. Famin, V. Cayol, A. Augier, L. Michon, and J.-F. Lénat (2015b). "Time-dependent displacements during and after the April 2007 eruption of Piton de la Fournaise, revealed by interferometric data". Journal of Volcanology and Geothermal Research 296, pp. 55-68. DoI: $10.1016 / \mathrm{j}$. jvolgeores . 2015 . 02.014.

Gailler, L. and J. Kauahikaua (2017). "Monitoring the cooling of the 1959 Kilauea Iki lava lake using surface magnetic measurements". Bulletin of Volcanology 79(6). DOI: $10.1007 / \mathrm{s} 00445-017-1119-7$.

Gailler, L., P. Labazuy, E. Régis, M. Bontemps, T. Souriot, G. Bacques, and B. Carton (2021). "Validation of a New UAV Magnetic Prospecting Tool for Volcano Monitoring and Geohazard Assessment". Remote Sensing 13(5), p. 894. DoI: 10.3390/rs13050894.

Gailler, L. and J.-F. Lénat (2012). "Internal architecture of La Réunion (Indian Ocean) inferred from geophysical data". Journal of Volcanology and Geothermal Research 221-222, pp. 83-98. Dor: $10.1016 / j$. jvolgeores.2012.01.015.

Gavazzi, B., L. Bertrand, M. Munschy, J. M. de Lépinay, M. Diraison, and Y. Géraud (2020). "On the Use of Aeromagnetism for Geological Interpretation: 1. Comparison of Scalar and Vector Magnetometers for Aeromagnetic Surveys and an Equivalent Source Interpolator for Combining, Gridding, and Transforming Fixed Altitude and Draping Data Sets". Journal of Geophysical Research: Solid Earth 125(5). DOI: 10 . 1029/2019jb018870.

Gavazzi, B., P. Le Maire, J. M. de Lépinay, P. Calou, and M. Munschy (2019). "Fluxgate three-component magnetometers for cost-effective ground, UAV and airborne magnetic surveys for industrial and academic geoscience applications and comparison with current industrial standards through case studies". Geomechanics for Energy and the Environment 20, p. 100117. Dor: $10.1016 / \mathrm{j}$.gete.2019.03.002.
Genthon, P., M. Rabinowicz, J. P. Foucher, and J. C. Sibuet (1990). "Hydrothermal circulation in an anisotropic sedimentary basin: Application to the Okinawa Back Arc Basin". Journal of Geophysical Research 95(B12), p. 19175. DOI: 10 . 1029 / jb095ib12p19175.

Got, J.-L., A. Peltier, T. Staudacher, P. Kowalski, and P. Boissier (2013). "Edifice strength and magma transfer modulation at Piton de la Fournaise volcano". Journal of Geophysical Research: Solid Earth 118(9), pp. 5040-5057. DoI: 10.1002/jgrb.50350.

Hunt, C. P., B. M. Moskowitz, and S. K. Banerjee (1995). "Magnetic Properties of Rocks and Minerals". AGU Reference Shelf. American Geophysical Union, pp. 189-204. DOI: 10.1029/rf@03p@189.

James, M. R., S. Robson, H. Pinkerton, and M. Ball (2006). "Oblique photogrammetry with visible and thermal images of active lava flows". Bulletin of Volcanology 69(1), pp. 105-108. DOI: 10.1007 / s00445๑०6- $0062-9$.

James, M., B. Carr, F. D’Arcy, A. Diefenbach, H. Dietterich, A. Fornaciai, E. Lev, E. Liu, D. Pieri, M. Rodgers, B. Smets, A. Terada, F. von Aulock, T. Walter, K. Wood, and E. Zorn (2020). "Volcanological applications of unoccupied aircraft systems (UAS): Developments, strategies, and future challenges". Volcanica, pp. 67-114. DoI: 10.30909/vol.03.01.67114.

Kaub, L., G. Keller, C. Bouligand, and J. M. G. Glen (2021). "Magnetic Surveys With Unmanned Aerial Systems: Software for Assessing and Comparing the Accuracy of Different Sensor Systems, Suspension Designs and Compensation Methods". Geochemistry, Geophysics, Geosystems 22(7). DOI: 10 . 1029 / $2021 \mathrm{gc} 009745$.

Kelfoun, K., T. Giachetti, and P. Labazuy (2010). "Landslide-generated tsunamis at Réunion Island". Journal of Geophysical Research 115(F4). Dor: 10.1029/ 2009jf001381.

Labazuy, P. (1996). "Recurrent landsliding events on the submarine flank of Piton de la Fournaise volcano (Réunion Island)". Volcano Instability on the Earth and Other Planets. Ed. by W. J. McGuire, A. P. Jones, and J. Neuberg. The Geological Society, pp. 293-305.

Lénat, J.-F. and P. Bachèlery (1990). "Structure et fonctionnement de la zone centrale du Piton de la Fournaise". Le Volcanisme de La Réunion, Monographie. Ed. by J. .-.-F. Lénat. Centre de Recherches Volcanologiques, Clermont-Ferrand, pp. 257-296.

Lénat, J.-F., P. Bachèlery, and O. Merle (2012a). "Anatomy of Piton de la Fournaise volcano (La Réunion, Indian Ocean)". Bulletin of Volcanology 74(9), pp. 1945-1961. Dor: 10.1007/s00445-012-0640-y.

- (2012b). "Anatomy of Piton de la Fournaise volcano (La Réunion, Indian Ocean)”. Bulletin of Volcanology 74(9), pp. 1945-1961. DoI: 10.1007 / s $00445-012$ 0640-y.

Lénat, J.-F., P. Bachèlery, and A. Peltier (2012c). "The interplay between collapse structures, hydrothermal 
systems, and magma intrusions: the case of the central area of Piton de la Fournaise volcano". Bulletin of Volcanology 74(2), pp. 407-421. DOI: 10 . 1007 / s00445-011-0535-3.

Lengliné, O., Z. Duputel, and V. Ferrazzini (2016). "Uncovering the hidden signature of a magmatic recharge at Piton de la Fournaise volcano using small earthquakes". Geophysical Research Letters 43(9), pp. 4255-4262. DoI: 10.1002/2016gl068383.

Merle, O. and J.-F. Lénat (2003). "Hybrid collapse mechanism at Piton de la Fournaise volcano, Reunion Island, Indian Ocean". Journal of Geophysical Research: Solid Earth 108(B3). DoI: 10 . 1029 / $2002 \mathrm{jb} 002014$.

Merle, O., P. Mairine, L. Michon, P. Bachèlery, and M. Smietana (2010). "Calderas, landslides and paleocanyons on Piton de la Fournaise volcano (La Réunion Island, Indian Ocean)". Journal of Volcanology and Geothermal Research 189(1-2), pp. 131-142. DOI: 10.1016/j. jvolgeores. 2009.11.001.

Michon, L., V. Cayol, L. Letourneur, A. Peltier, N. Villeneuve, and T. Staudacher (2009). "Edifice growth, deformation and rift zone development in basaltic setting: Insights from Piton de la Fournaise shield volcano (Réunion Island)". Journal of Volcanology and Geothermal Research 184(1-2), pp. 14-30. DOI: 10 . 1016/j . jvolgeores. 2008.11.002.

Michon, L., A. Di Muro, N. Villeneuve, C. Saint-Marc, P. Fadda, and F. Manta (2013). "Explosive activity of the summit cone of Piton de la Fournaise volcano (La Réunion island): A historical and geological review". Journal of Volcanology and Geothermal Research 264, pp. 117-133. Dor: $10.1016 / \mathrm{j}$. jvolgeores . 2013.06 . 012.

Michon, L., V. Ferrazzini, and A. Di Muro (2016). "Magma paths at Piton de la Fournaise Volcano". Active Volcanoes of the Southwest Indian Ocean. Ed. by P. Bachèlery, J.-F. Lénat, A. Di Muro, and L. Michon. Springer Berlin Heidelberg, pp. 91-106. DoI: 10 . 1007/978-3-642-31395-0_7.

Michon, L., V. Ferrazzini, A. Di Muro, N. Villeneuve, and V. Famin (2015). "Rift zones and magma plumbing system of Piton de la Fournaise volcano: How do they differ from Hawaii and Etna?" Journal of Volcanology and Geothermal Research 303, pp. 112-129. Dor: $10.1016 / \mathrm{j}$. jvolgeores. 2015.07.031.

Michon, L. and F. Saint-Ange (2008). "Morphology of Piton de la Fournaise basaltic shield volcano (La Réunion Island): Characterization and implication in the volcano evolution". Journal of Geophysical Research 113(B3). DoI: 10.1029/2005jb004118.

Michon, L., F. Saint-Ange, P. Bachèlery, N. Villeneuve, and T. Staudacher (2007a). "Role of the structural inheritance of the oceanic lithosphere in the magmatotectonic evolution of Piton de la Fournaise volcano (La Réunion Island)". Journal of Geophysical Research: Solid Earth 112(B4). Dor: 10.1029/2006jb004598.
Michon, L., T. Staudacher, V. Ferrazzini, P. Bachèlery, and J. Marti (2007b). "April 2007 collapse of Piton de la Fournaise: A new example of caldera formation". Geophysical Research Letters 34(21). DoI: 10 . 1029/2007g1031248.

Michon, L., N. Villeneuve, T. Catry, and O. Merle (2008). "How summit calderas collapse on basaltic volcanoes: new insights from the April 2007 caldera collapse of Piton de la Fournaise volcano". IOP Conference Series: Earth and Environmental Science 3, p. 012025. DOI: $10.1088 / 1755-1307 / 3 / 1 / 012025$.

Nabighian, M. N., V. J. S. Grauch, R. O. Hansen, T. R. LaFehr, Y. Li, J. W. Peirce, J. D. Phillips, and M. E. Ruder (2005). "The historical development of the magnetic method in exploration". GEOPHYSICS 70(6), 33ND-61ND. DoI: 10.1190/1.2133784.

Oehler, J.-F., J.-F. Lénat, and P. Labazuy (2008). "Growth and collapse of the Reunion Island volcanoes”. Bulletin of Volcanology 70(6), pp. 717-742. Dor: 10.1007/s00445-007-0163-0.

Patrick, M. R. and C.-N. Witzke (2011). Thermal mapping of Hawaiian volcanoes with ASTER satellite data. US Department of the Interior.

Peltier, A., P. Bachèlery, and T. Staudacher (2009a). "Magma transport and storage at Piton de La Fournaise (La Réunion) between 1972 and 2007: A review of geophysical and geochemical data". Journal of Volcanology and Geothermal Research 184(1-2), pp. 93108. Dor: $10.1016 / \mathrm{j}$. jvolgeores. 2008.12.008.

Peltier, A., F. Beauducel, N. Villeneuve, V. Ferrazzini, A. Di Muro, A. Aiuppa, A. Derrien, K. Jourde, and B. Taisne (2016). "Deep fluid transfer evidenced by surface deformation during the 2014-2015 unrest at Piton de la Fournaise volcano". Journal of Volcanology and Geothermal Research 321, pp. 140-148. DoI: 10 . 1016/j. jvolgeores. 2016.04.031.

Peltier, A., V. Ferrazzini, T. Staudacher, and P. Bachèlery (2005). "Imaging the dynamics of dyke propagation prior to the 2000-2003 flank eruptions at Piton de La Fournaise, Reunion Island". Geophysical Research Letters 32(22). DoI: 10.1029/2005gl023720.

Peltier, A., V. Ferrazzini, A. Di Muro, P. Kowalski, N. Villeneuve, N. Richter, O. Chevrel, J. L. Froger, A. Hrysiewicz, M. Gouhier, D. Coppola, L. Retailleau, F. Beauducel, L. Gurioli, P. Boissier, C. Brunet, P. Catherine, F. Fontaine, F. Lauret, L. Garavaglia, J. Lebreton, K. Canjamale, N. Desfete, C. Griot, A. Harris, S. Arellano, M. Liuzzo, S. Gurrieri, and M. Ramsey (2021). "Volcano Crisis Management at Piton de la Fournaise (La Réunion) during the COVID-19 Lockdown". Seismological Research Letters 92(1), pp. 3852. DoI: $10.1785 / 0220200212$.

Peltier, A., J.-L. Got, N. Villeneuve, P. Boissier, T. Staudacher, V. Ferrazzini, and A. Walpersdorf (2015). "Long-term mass transfer at Piton de la Fournaise volcano evidenced by strain distribution derived from GNSS network". Journal of Geophys- 
ical Research: Solid Earth 120(3), pp. 1874-1889. DOI: $10.1002 / 2014$ jb011738.

Peltier, A., F. Massin, P. Bachèlery, and A. Finizola (2012). "Internal structure and building of basaltic shield volcanoes: the example of the Piton de La Fournaise terminal cone (La Réunion)". Bulletin of Volcanology 74(8), pp. 1881-1897. DOI: 10.1007 / s00445-012-0636-7.

Peltier, A., T. Staudacher, and P. Bachèlery (2010). "New behaviour of the Piton de La Fournaise volcano feeding system (La Réunion Island) deduced from GPS data: Influence of the 2007 Dolomieu caldera collapse". Journal of Volcanology and Geothermal Research 192(1-2), pp. 48-56. DoI: 10.1016/j . jvolgeores. 2010.02 .007$.

Peltier, A., T. Staudacher, P. Bachèlery, and V. Cayol (2009b). "Formation of the April 2007 caldera collapse at Piton de La Fournaise volcano: Insights from GPS data". Journal of Volcanology and Geothermal Research 184(1-2), pp. 152-163. DoI: $10.1016 / \mathrm{j}$. jvolgeores.2008.09.009.

Peltier, A., N. Villeneuve, V. Ferrazzini, S. Testud, T. H. Ali, P. Boissier, and P. Catherine (2018). "Changes in the Long-Term Geophysical Eruptive Precursors at Piton de la Fournaise: Implications for the Response Management". Frontiers in Earth Science 6. DoI: 10. 3389/feart. 2018.00104.

Poland, M. P., A. Peltier, A. Bonforte, and G. Puglisi (2017). "The spectrum of persistent volcanic flank instability: A review and proposed framework based on Kilauea, Piton de la Fournaise, and Etna". Journal of Volcanology and Geothermal Research 339, pp. 6380. Dor: $10.1016 / j$. jvolgeores. 2017.05.004.

Prôno, E., J. Battaglia, V. Monteiller, J.-L. Got, and V. Ferrazzini (2009). "P-wave velocity structure of Piton de la Fournaise volcano deduced from seismic data recorded between 1996 and 1999". Journal of Volcanology and Geothermal Research 184(1-2), pp. 4962. Dor: $10.1016 / j$. jvolgeores . 2008.12.009.

Roult, G., A. Peltier, B. Taisne, T. Staudacher, V. Ferrazzini, and A. Di Muro (2012). "A new comprehensive classification of the Piton de la Fournaise activity spanning the 1985-2010 period. Search and analysis of short-term precursors from a broad-band seismological station". Journal of Volcanology and Geothermal Research 241-242, pp. 78-104. DoI: $10.1016 / j$. jvolgeores.2012.06.012.

Smittarello, D., V. Cayol, V. Pinel, A. A. Peltier, J.-L. Froger, and V. Ferrazzini (2019). "Magma Propagation at Piton de la Fournaise From Joint Inversion of
InSAR and GNSS". Journal of Geophysical Research: Solid Earth 124(2), pp. 1361-1387. DoI: 10.1029 / $2018 \mathrm{jb} 016856$.

Staudacher, T. (2010). "Field observations of the 2008 summit eruption at Piton de la Fournaise (Ile de La Réunion) and implications for the 2007 Dolomieu collapse". Journal of Volcanology and Geothermal Research 191(1-2), pp. 60-68. DOI: $10.1016 / \mathrm{j}$. jvolgeores.2010.01.012.

Staudacher, T., V. Ferrazzini, A. Peltier, P. Kowalski, P. Boissier, P. Catherine, F. Lauret, and F. Massin (2009). "The April 2007 eruption and the Dolomieu crater collapse, two major events at Piton de la Fournaise (La Réunion Island, Indian Ocean)". Journal of Volcanology and Geothermal Research 184(1-2), pp. 126137. Dor: $10.1016 / \mathrm{j}$. jvolgeores. 2008.11.005.

Tridon, M., V. Cayol, J.-L. Froger, A. Augier, and P. Bachèlery (2016). "Inversion of coeval shear and normal stress of Piton de la Fournaise flank displacement". Journal of Geophysical Research: Solid Earth 121(11), pp. 7846-7866. Dor: 10.1002/2016jb013330.

Urai, M., N. Geshi, and T. Staudacher (2007). "Size and volume evaluation of the caldera collapse on Piton de la Fournaise volcano during the April 2007 eruption using ASTER stereo imagery". Geophysical Research Letters 34(22). DOI: 10.1029/2007gl031551.

Villeneuve, N. and P. Bachèlery (2006). "Revue de la typologie des éruptions au Piton de La Fournaise, processus et risques volcaniques associés". Cybergeo. Dor: 10.4000/cybergeo. 2536.

Wessels, R. L., R. G. Vaughan, M. R. Patrick, and M. L. Coombs (2013). "High-resolution satellite and airborne thermal infrared imaging of precursory unrest and 2009 eruption at Redoubt Volcano, Alaska". Journal of Volcanology and Geothermal Research 259, pp. 248-269. Dor: 10.1016/j . jvolgeores. 2012 . 04 . 014.

Zlotnicki, J., J. L. Le Mouël, J. C. Delmond, C. Pambrun, and H. Delorme (1993). "Magnetic variations on Piton de la Fournaise volcano. Volcanomagnetic signals associated with the November 6 and 30, 1987, eruptions". Journal of Volcanology and Geothermal Research 56(3), pp. 281-296. Dor: 10 . 1016/03770273 (93) $90021-i$.

Zurek, J. and G. Williams-Jones (2013). "The shallow structure of Kilauea caldera from high-resolution Bouguer gravity and total magnetic anomaly mapping: Insights into progressive magma reservoir growth". Journal of Geophysical Research: Solid Earth 118(7), pp. 3742-3752. DoI: $10.1002 /$ jgrb. 50243 . 